\title{
Microstructural and Cavitation Erosion Behavior of the CuAlNi Shape Memory Alloy
}

\author{
Tatjana Volkov-Husović $^{1}{ }^{10}$, Ivana Ivanić ${ }^{2}$, Stjepan Kožuh ${ }^{2}$, Sanja Stevanović ${ }^{3}$, Milica Vlahović ${ }^{3, *}$, \\ Sanja Martinović ${ }^{3}$ (D), Srecko Stopic ${ }^{4, *}$ and Mirko Gojić ${ }^{2}$
}

1 Department of Metallurgical Engineering, Faculty of Technology and Metallurgy, University of Belgrade, Karnegijeva 4, 11000 Belgrade, Serbia; tatjana@tmf.bg.ac.rs

2 Department for Physical Metallurgy, Faculty of Metallurgy, University of Zagreb, Aleja Narodnih Heroja 3, 44000 Sisak, Croatia; iivanic@simet.hr (I.I.); kozuh@simet.hr (S.K.); gojic@simet.hr (M.G.)

3 Department of Electrochemistry, Institute of Chemistry, Technology and Metallurgy-National Institute of the Republic of Serbia, University of Belgrade, Njegoševa 12, 11000 Belgrade, Serbia; sanjas@ihtm.bg.ac.rs (S.S.); s.martinovic@ihtm.bg.ac.rs (S.M.)

4 IME Process Metallurgy and Metal Recycling, RWTH Aachen University, 52056 Aachen, Germany

* Correspondence: m.vlahovic@ihtm.bg.ac.rs (M.V.); sstopic@ime-aachen.de (S.S.); Tel.: +49-381-11-3370-698 (M.V.); +49-176-7826-1674 (S.S.)

check for

updates

Citation: Volkov-Husović, T.; Ivanić,

I.; Kožuh, S.; Stevanović, S.; Vlahović,

M.; Martinović, S.; Stopic, S.; Gojić, M.

Microstructural and Cavitation

Erosion Behavior of the CuAlNi

Shape Memory Alloy. Metals 2021, 11,

997. https://doi.org/10.3390/

met11070997

Academic Editor: Alexander

V. Shelyakov

Received: 27 April 2021

Accepted: 16 June 2021

Published: 22 June 2021

Publisher's Note: MDPI stays neutral with regard to jurisdictional claims in published maps and institutional affiliations.

Copyright: (c) 2021 by the authors. Licensee MDPI, Basel, Switzerland. This article is an open access article distributed under the terms and conditions of the Creative Commons Attribution (CC BY) license (https:// creativecommons.org/licenses/by/ $4.0 /)$.

\begin{abstract}
Microstructural and cavitation erosion testing was carried out on Cu-12.8Al-4.1Ni (wt. \%) shape memory alloy (SMA) samples produced by continuous casting followed by heat treatment consisting of solution annealing at $885^{\circ} \mathrm{C}$ for $60 \mathrm{~min}$ and, later, water quenching. Cavitation resistance testing was applied using a standard ultrasonic vibratory cavitation set up with stationary specimen. Surface changes during the cavitation were monitored by metallographic analysis using an optical microscope (OM), atomic force microscope (AFM), and scanning electron microscope (SEM) as well as by weight measurements. The results revealed a martensite microstructure after both casting and quenching. Microhardness value was higher after water quenching than in the as-cast state. After 420 min of cavitation exposure, a negligible mass loss was noticed for both samples. Based on the obtained results, both samples showed excellent cavitation resistance. Mass loss and morphological analysis of the formed pits indicated better cavitation resistance for the as-cast state (L).
\end{abstract}

Keywords: cavitation erosion; optical microscopy; electron microscopy; atomic force microscopy

\section{Introduction}

Among the variety of advanced materials with exceptional properties and applications, shape memory alloys (SMAs) have a unique ability to return to previously defined shapes or sizes if subjected to the relevant thermal treatment. The memory effect can be reached only in the presence of specific phase transformation, reversible austenite to the martensite phase. The conditions necessary for such phase transformation include mechanical (loading) or thermal (cooling and heating) methods.

Based on the literature, there are several basic types of SMAs, such as Ni-Ti (nitinol), $\mathrm{Cu}$-based, and Fe-based alloys [1,2]. All of the above types have advantages and disadvantages, while economical aspects such as the price can be very important for material selection and application. Precisely, the economic effect (low price) is the main advantage of Cu-based SMAs compared with other SMAs. Namely, these alloys (Cu-Al-Ni alloys) can be applied in various industrial fields, especially when high transformation temperatures are required (near $200^{\circ} \mathrm{C}$ ), thanks to their high thermal stability and high transformation temperatures.

The selection for application of this group of alloys is affected by their characteristics such as high transformation temperatures (high thermal stability at elevated temperatures, above $200{ }^{\circ} \mathrm{C}$ ); high corrosion resistance; high resistance to degradation of functional properties during aging processes; and, last but not least, the reasonable cost. Some of the 
usual applications include the different types of engineering sectors, such as automotive, aerospace, medical and biomedical, and construction [3-5].

Processing routes for the synthesis of $\mathrm{Cu}-\mathrm{Al}-\mathrm{Ni}$ shape memory alloys can be as follows:

1. Casting route (conventional casting route with and without quaternary addition);

2. Powder metallurgy route (mechanical alloying followed by sintering process, mechanical alloying followed by hot pressing and extrusion process, mechanical alloying of pre-alloyed powders followed by hot isostatic pressing, mechanical alloying of elemental and pre-alloyed powders followed by sintering and hot rolling);

3. Rapid solidification processing route;

4. Spray casting route.

In recent years, the continuous casting technique has been one of the most used technologies for the production of SMAs. This method is commonly used thanks to the special competitive growth mechanism of crystal and formation of cast products, which allowed to produce a favorable texture [6-8]. Functional properties strongly depend on microstructural changes of SMAs.

Different types of martensite plates $\left(\beta^{\prime}{ }_{1}, \gamma^{\prime}{ }_{1}\right)$ and phases can occur, depending on the chemical composition, production technology, heat treatment, and stress conditions of $\mathrm{Cu}-\mathrm{Al}-\mathrm{Ni}$ shape memory alloys [8-10].

Cavitation presents a complex phenomenon of formation, growth, and condensation of bubbles in fluid flow. When those formed bubbles are transported by fluid flow in the region of pressure higher than the evaporation pressure, they disappear very fast. Cavitation begins even in the presence of positive pressures that is equal or close to the pressure of saturated vapor of the fluid at a given temperature. Extremely large pulses of stress are generated during the collapse of the bubbles, and the rapid repetition of the stress on nearby materials causes severe erosion [11]. The shock waves and micro jets can erode the surfaces of materials under vaporous cavitation conditions. This phenomenon is additionally referred to as cavitation erosion, vaporous cavitation, cavitation pitting, cavitation fatigue, and liquid impact erosion. The result of cavitation is fatigue wear, while cavitation resistance is the ability of a material to confront the degradation caused by cavitation.

Cavitation phenomena were studied in many papers and well described for the materials regarding many applications [12-14]. Cavitation damage test is usually used for metallic materials [15-18] and coatings [17-19], with great interest on material properties' influence [20] such as cobalt alloys [21], WC-12Co coatings [22], and Monel K-500 alloy [19]. Among shape memory alloys, the cavitation erosion was tested primarily for nitinol alloy [23-25] and Fe-based shape memory alloy [26], while for CuAlNi alloy, references were not observed. Moreover, non-metallic materials were investigated for the cavitation resistance behavior, such as ceramics [27-30] and polymer materials [31-33].

Based on the lack of literature data related to the cavitation behavior/degradation of $\mathrm{Cu}-\mathrm{Al}-\mathrm{Ni}$ SMAs, this paper represents the attempt to investigate the cavitation behavior of $\mathrm{Cu}-\mathrm{Al}-\mathrm{Ni} \mathrm{SMAs}$ exposed to cavitation.

\section{Experimental}

\subsection{Synthesis}

The polycrystalline $\mathrm{Cu}-12.8 \mathrm{Al}-4.1 \mathrm{Ni}$ (wt.\%) shape memory alloy was prepared from pure raw materials of copper, aluminum, and nickel in a vacuum induction furnace. The heating temperature was $1240{ }^{\circ} \mathrm{C}$. A solid bar of $8 \mathrm{~mm}$ was produced directly from the melt by means of a device for the vertical continuous casting connected with a vacuum induction furnace. Continuous casting of the bar was carried out with a speed of $320 \mathrm{~mm} / \mathrm{min}$ (as-cast state, sample L). After the casting, the heat treatment procedure was performed by the solution annealing at $885^{\circ} \mathrm{C}$ for $60 \mathrm{~min}$ followed by water quenching (quenched state, sample K-2). 


\subsection{Cavitation Test}

Cavitation erosion test was performed using the ultrasonic vibration method (with stationary sample), according to ASTM G32 standard [32]. The experimental set-up is described in detail in previous papers $[18,20,30,31]$. The gap between the surface of the samples and the transformer probe was $0.5 \mathrm{~mm}$. The test was carried out with distilled water as the medium of room temperature to avoid corrosion effects. Samples' dimensions were diameter of $8 \mathrm{~mm}$ and height of $6 \mathrm{~mm}$. The diameter of the sample was the same as the diameter of the solid bar and the height of the sample was adjusted to the followed AFM testing and performance of the holder of the sample. Three replicate specimens were used for the measurements, while each presented result is the mean value of the obtained results.

\subsection{Methods for Monitoring the Cavitation Testing}

\subsubsection{Mass Loss}

Mass measurements of the test specimens during the experiment were performed on an analytical balance with an accuracy of $\pm 0.1 \mathrm{mg}$. Before being weighted, the test specimens were dried in a dryer at $110^{\circ} \mathrm{C}$ for an hour.

\subsubsection{Optical Microscopy}

The surface of specimens was tested by trinocular metallurgical microscope (EUME, EU Instruments, Gramma Libero, Belgrade) using different magnitudes to analyze the effect of the surface erosion.

\subsubsection{SEM}

Microstructural characterization was performed on prepared metallographic samples. Samples were abraded by different grid emery papers (400-1200); polished in an $\mathrm{Al}_{2} \mathrm{O}_{3}$ solution; and etched in a solution containing $2.5 \mathrm{~g} \mathrm{FeCl}_{3}, 10 \mathrm{~mL} \mathrm{HCl}$, and $48 \mathrm{~mL}$ of methanol.

\subsubsection{AFM}

The surface morphology was investigated by atomic force microscopy (AFM) with NanoScope 3D (Veeco, Santa Barbara, CA, USA) operated in contact mode under ambient conditions. Silicon Nitride probes with a spring constant of 20-60 N/m were used.

\subsubsection{Microhardness}

Measurement of microhardness of samples before and after heat treatment was performed using the Vickers method (HV10).

\section{Results and Discussion}

Figure 1 shows optical micrographs of the CuAlNi alloy after both continuous casting and quenching. Solution annealing (followed by quenching in water) as a heat treatment procedure in Cu-based shape memory alloys must be performed in order to achieve order in the alloy's structure, stabilization of the phase transformation temperatures, as well as a fully martensitic microstructure. The grain size of solidified alloys was determined by the amount of undercooling prior to crystallization. In Figure 1, grain boundaries are clearly visualized before and after heat treatment. The results showed that the size of grains increases after solution annealing and quenching in water. As can be seen, the micrographs of specimens (Figure 1) show the typical martensite microstructure. The continuous casting at a cooling rate of $320 \mathrm{~mm} / \mathrm{min}$ was satisfied with the formation of martensite microstructure. Martensite laths have different orientations into particular grains. It can be explained by the nucleation of groups of martensite plates in numerous places within the grain and the creation of local strain within the grain [33,34]. 

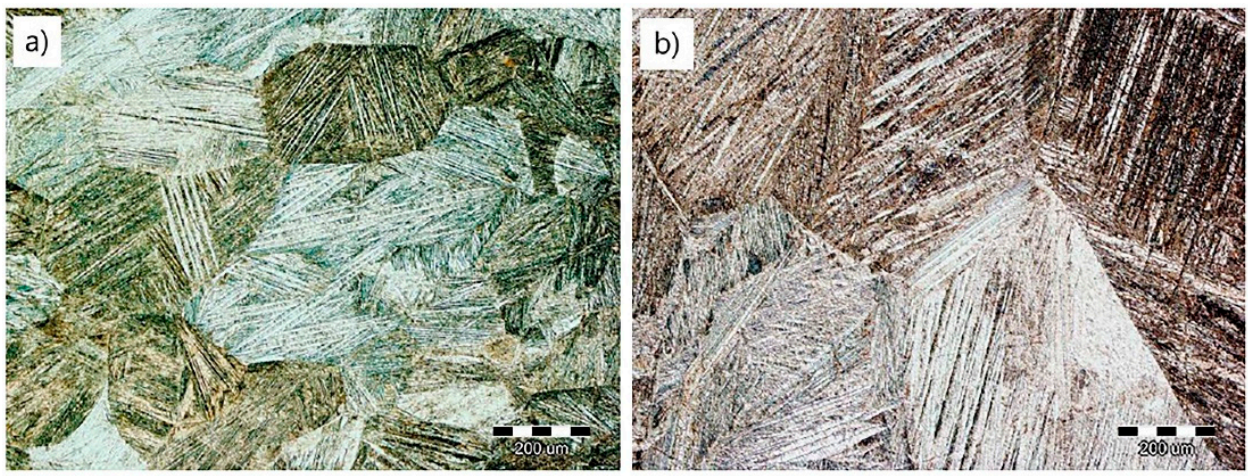

Figure 1. Optical micrographs of $\mathrm{CuAlNi}$ shape memory alloy in the as-cast state (a) and after solution annealing at $885^{\circ} \mathrm{C} / 60 \mathrm{~min} \mathrm{H}_{2} \mathrm{O}(\mathbf{b})$.

Martensite microstructure obtained by OM was confirmed by SEM micrographs (Figure 2). This microstructure is the result of the beta-phase of CuAlNi alloys transforming into a martensite phase by cooling below the $\mathrm{M}_{\mathrm{s}}$-temperature. Martensite appears primarily as needle-like martensite. This microstructure consists of self-accommodating needle-like shape martensite in as-cast state and after heat treatment, which is characteristic for the $\beta^{\prime}{ }_{1}$ martensite in the CuAlNi alloy [33].
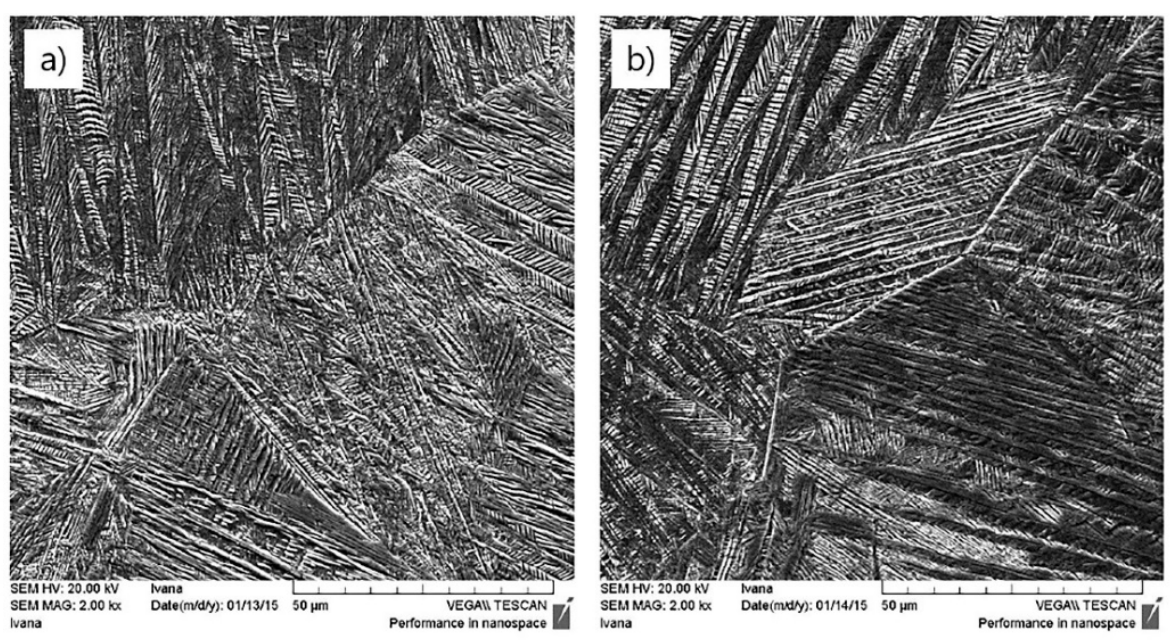

Figure 2. SEM micrographs of CuAlNi shape memory alloy in the as-cast state (a) and after solution annealing at $885^{\circ} \mathrm{C} / 60 \mathrm{~min} \mathrm{H}_{2} \mathrm{O}(\mathbf{b})$.

Average values of microhardness testing showed that, after quenching in water, microhardness is higher ( 480 HV10) than that in the as-cast state (344 HV10). Based on the obtained results for the mass loss (Figure 3), the sample after quenching exhibits higher values in comparison with the as-cast state. However, it is important to mention that both samples exhibited excellent resistance to cavitation erosion. After $420 \mathrm{~min}$ of exposure to cavitation testing, the mass loss was $0.0014 \mathrm{~g}$ for the specimen in a quenched state (Figure 3), while the mass loss was $0.0004 \mathrm{~g}$ for the sample after casting. 


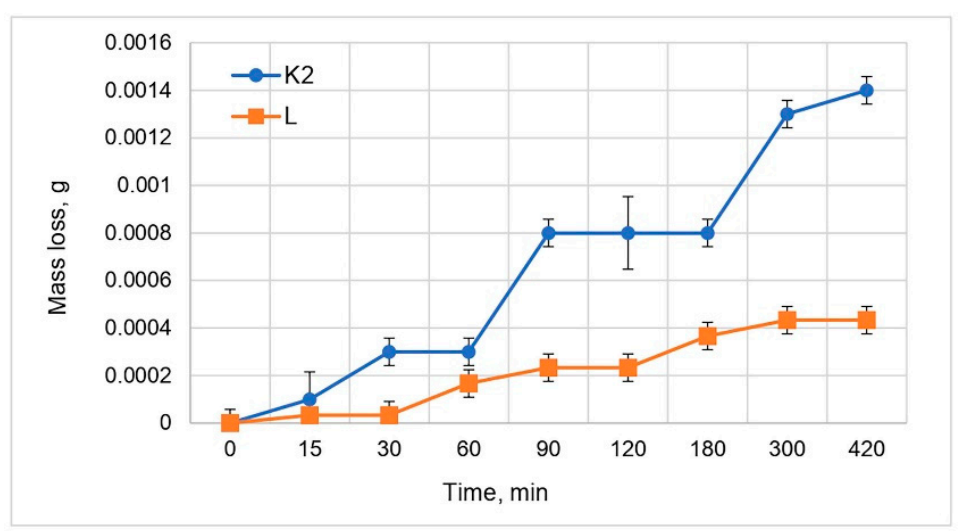

Figure 3. Mass loss during cavitation testing of specimens in the different states, as-cast (L) and quenched (K2), at $885^{\circ} \mathrm{C} / 60 \mathrm{~min} \mathrm{H}_{2} \mathrm{O}$.

Cavitation erosion is a phenomenon that includes not only properties of liquid, but also the properties of material, for example, hardness, microstructure, grain size of material, and so on. It is known [20] that the material with a homogeneous and fine-grained structure has the highest cavitation erosion resistance, good mechanical properties, and high corrosion resistance. In the literature, there is no information about cavitation resistance testing of $\mathrm{CuAlNi}$ shape memory alloys. It was found that the average grain size of samples in as-cast condition was about $150 \mu \mathrm{m}$ (Figures $1 \mathrm{a}$ and 2a), while after quenching, the average grain size was several times higher, up to about $1 \mathrm{~mm}$ (Figures $1 \mathrm{~b}$ and $2 \mathrm{~b}$ ). The finer grain size after continuous casting of $\mathrm{CuAlNi}$ alloy resulted in better resistance to cavitation erosion than the sample in heat treated state (Figure 3). Moreover, it was observed that the CuAlNi alloy in as-cast condition is softer (344 HV10) than after quenching (480 HV10), which suggested that resistance to cavitation erosion is better after quenching than that in the as-casted state. This is in contrast to the behaviour of other materials, which show that higher hardness of the materials gives better resistance to cavitation erosion [20]. This area definitely requires further investigation.

In addition to grain size and hardness, resistance to cavitation erosion is related to the microstructure in as-casted and heat treated condition. It is known that CuAlNi shape memory alloys undergo a single transformation $\left(\beta \rightarrow \beta_{1}{ }^{\prime}\right.$ or $\left.\beta \rightarrow \gamma_{1}{ }^{\prime}\right)$ or a mixed transformation $\left(\beta \rightarrow \beta_{1}^{\prime}+\gamma_{1}^{\prime}\right)$, which depends on the alloy's chemical composition [35]. The previous works [36] confirmed that, after heat treatment in CuAlNi microstructure, along with $\beta_{1}^{\prime}$ martensite, $\gamma_{1}^{\prime}$ martensite also appears, while in the casted state, only $\beta_{1}{ }^{\prime}$ martensite exists. This indicates that the different types of martensite affect alloys' cavitation erosion resistance. The difference in the obtained microstructures before and after heat treatment can be explained by possible changes in martensite morphology. Thus, the mixed martensite microstructure $\left(\beta_{1}^{\prime}+\gamma_{1}{ }^{\prime}\right)$ has better resistance to cavitation erosion than the single martensite $\beta_{1}{ }^{\prime}$ microstructure. Self-accommodating zig-zag $\beta_{1}{ }^{\prime}$ martensite benefits to alloys in terms of lower cavitation resistance, while the presence of $\gamma_{1}{ }^{\prime}$ martensite benefits to alloys in terms of better cavitation resistance. This is confirmed by cavitation erosion tests (Figure 3) showing that mass loss of CuAlNi alloy after quenching was lower than for as-cast state. It can be assumed that appearance of $\gamma_{1}^{\prime}$ martensite during cooling has an effect on deformation processes of the CuAlNi alloy. This effect makes this alloy capable of obtaining bigger elastic deformations than for the as-casted condition, in this way delaying the plastic deformation process and fracture, and the consequent weight loss occurs [37]. J. Peña et al. observed that the critical stress for inducing martensite and the capacity of energy absorption related to the different deformation modes are the important parameters to justify the wear resistance of $\mathrm{CuZnAl}$ shape memory alloy.

Figure 4 shows the micrographs of microstructure in both as-cast and quenched states, before and after $420 \mathrm{~min}$ of exposure to cavitation testing obtained by an optical microscope. 
According to those results, changes in microstructure are small and, for better detection, need larger magnification.

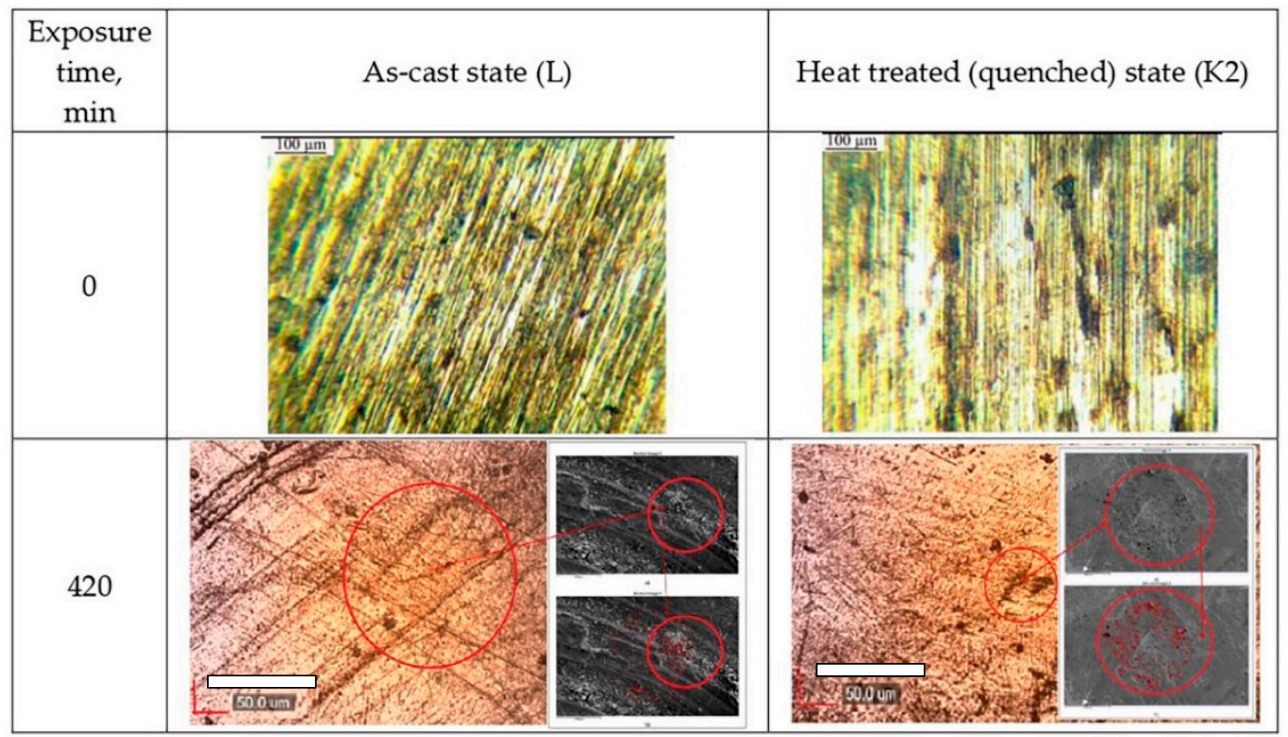

Figure 4. Micrographs of samples before and after $420 \mathrm{~min}$ of cavitation exposure.

In Figure 4, the microstructure of the as cast sample (L) after 420 min of cavitation resistance testing is given. The first part of figure was taken by optical microscope, and some parts with pits are observed. Marked typical areas with pits are also given as SEM microphotographs. This marked area is taken for better visibility of the formed pits and is presented separately in Figure 5. The same approach was performed for the sample after heat treatment (K2), and is presented in Figure 4.

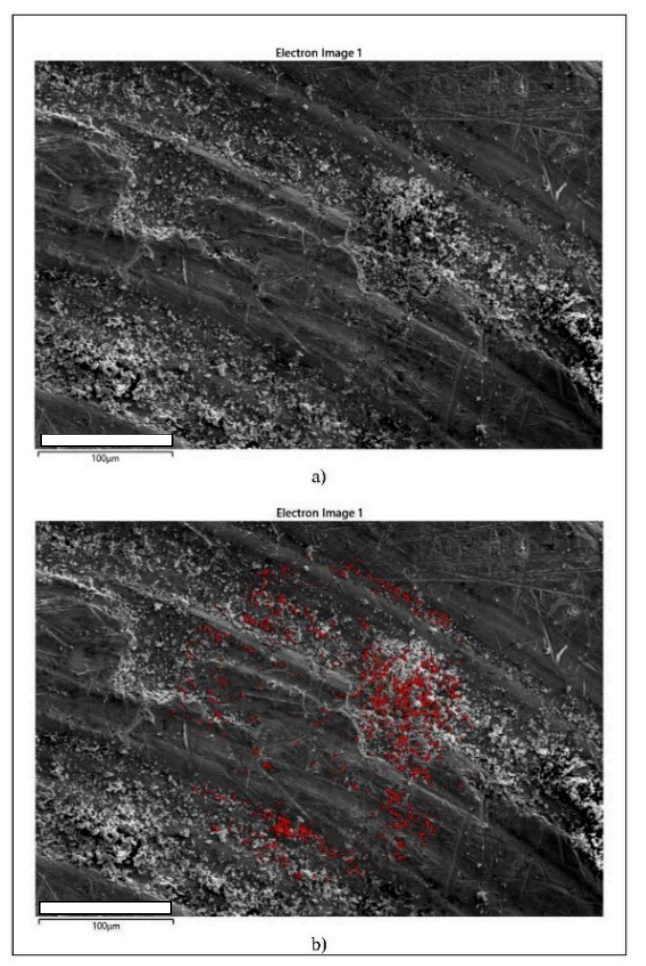

Figure 5. SEM of the as-cast state sample (L) after $420 \mathrm{~min}$ of cavitation exposure (the scale bar: $100 \mu \mathrm{m}$ ). 
Figures $5 a$ and 6a present SEM micrographs of the sample after 420 min of exposure to cavitation. In Figures $5 \mathrm{~b}$ and $6 \mathrm{~b}$, the damaged area is colored for further image analysis in order to perform the analysis of morphological parameters, which describes the formed pits. The results are given in Table 1.

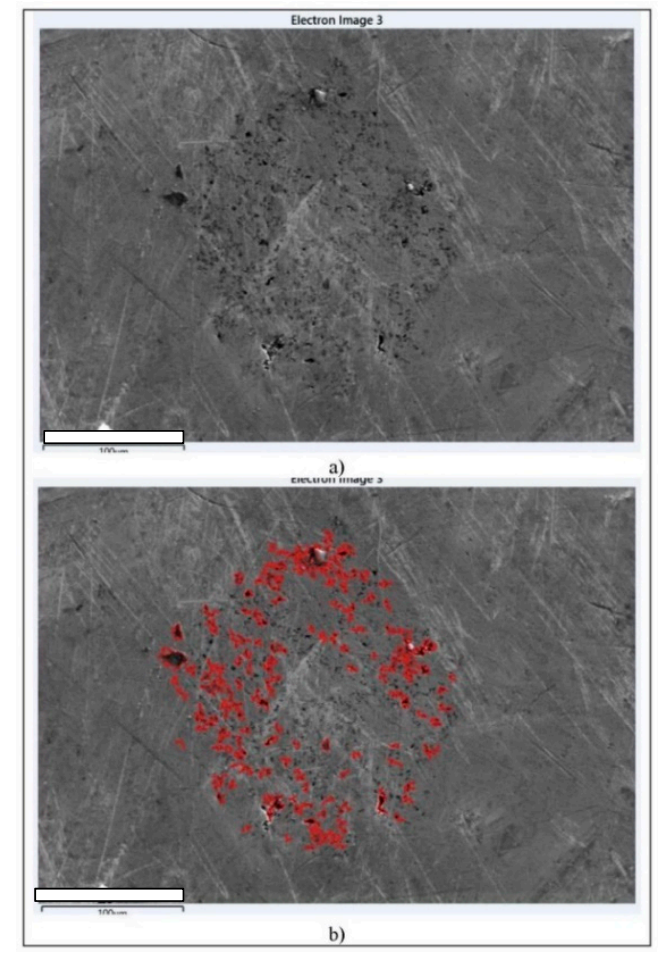

Figure 6. SEM of the sample after quenching and $420 \mathrm{~min}$ of cavitation exposure (K2) (the scale bar: $100 \mu \mathrm{m})$.

Table 1. Analysis of morphological parameters for the samples after exposure to cavitation testing (420 $\mathrm{min})$.

\begin{tabular}{ccc}
\hline \multirow{2}{*}{ Parameter } & As-Cast State (L) & Heat-Treated (Quenched) State (K2) \\
\cline { 2 - 3 } & \multicolumn{2}{c}{ Average Values } \\
\hline Area, $\mu \mathrm{m}$ & 1.235312 & 36.13774 \\
Diameter $(\max ), \mu \mathrm{m}$ & 1.334329 & 9.553893 \\
Diameter (min), $\mu \mathrm{m}$ & 0.773391 & 3.257734 \\
Diameter (mean), $\mu \mathrm{m}$ & 1.051157 & 6.288539 \\
Radius (min), $\mu \mathrm{m}$ & 0.337882 & 0.724588 \\
Perimeter, $\mu \mathrm{m}$ & 1.858238 & 34.40823 \\
Perimeter 2, $\mu \mathrm{m}$ & 2.086906 & 47.0361 \\
Fractal dimension & 0.009532 & 1.25286 \\
Perimeter 3, $\mu \mathrm{m}$ & 2.147028 & 38.70619 \\
\hline
\end{tabular}

These results are consistent with the results of mass loss (Figure 3). It has to be taken into account that the obtained results for both samples suggested very good cavitation resistance; however, there are differences in samples' behavior. Moreover, the formation of the typical cavitation ring was detected on the sample after heat treatment (K2), unlike on the sample in the as-cast state (L), which also indicates better cavitation resistance of the sample in the as-cast state (L).

Based on the obtained results for morphological analysis and parameters listed in Table 1, differences between the formed pits after $420 \mathrm{~min}$ can be observed. The results for the sample as cast (L) suggested better resistance to the cavitation erosion testing. Average 
values for observed parameters, such as average values for area, diameter, and perimeter of the formed pits, are smaller compared with values for the heat-treated state.

SEM micrographs of the investigated samples are given in Figure 7, while Tables 2 and 3 provide the results of EDS analysis.

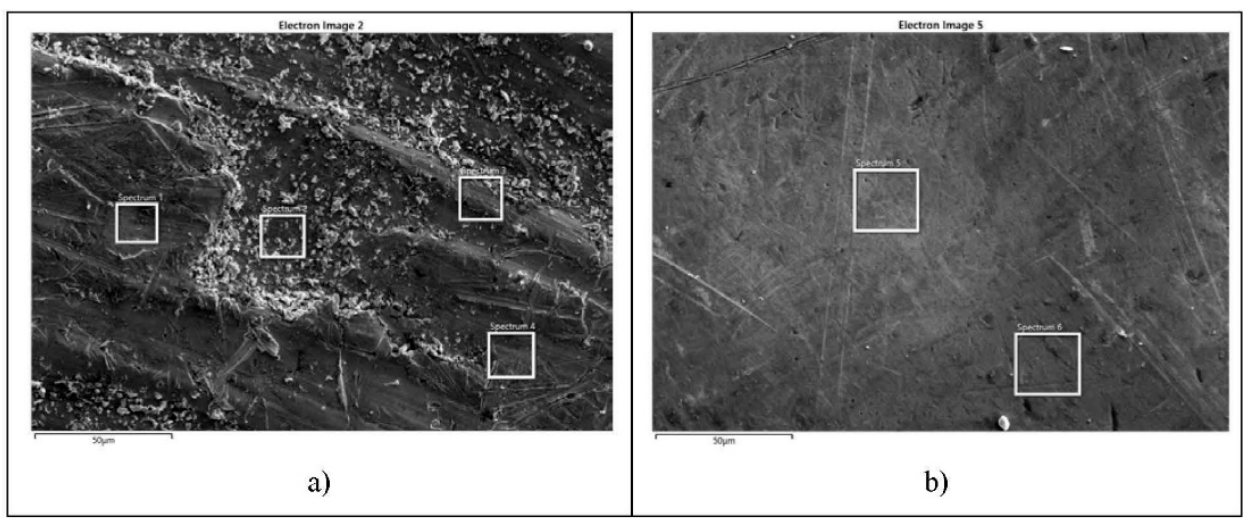

Figure 7. SEM for EDS of the sample after (a) $420 \mathrm{~min}$ of cavitation exposure of as-cast state (L) and (b) quenching and $420 \mathrm{~min}$ of cavitation exposure (K2).

Table 2. EDS analysis of as-cast state (L).

\begin{tabular}{|c|c|c|c|c|}
\hline \multirow{2}{*}{$\begin{array}{c}\text { Result Type } \\
\text { Spectrum Label }\end{array}$} & \multicolumn{4}{|c|}{ Weight \% } \\
\hline & Spectrum 1 & Spectrum 2 & Spectrum 3 & Spectrum 4 \\
\hline $\mathrm{L}$ & 12.55 & 12.41 & 12.93 & 12.9 \\
\hline $\mathrm{Ni}$ & 4.73 & 5.65 & 4.8 & 4.62 \\
\hline $\mathrm{Cu}$ & 82.72 & 81.94 & 82.26 & 82.48 \\
\hline Total & 100 & 100 & 100 & 100 \\
\hline Statistics & Al & & & $\mathrm{Cu}$ \\
\hline Max & 12.93 & & & 82.72 \\
\hline Min & 12.41 & & & 81.94 \\
\hline Average & 12.7 & & & 82.35 \\
\hline Standard deviation & 0.26 & & & 0.33 \\
\hline
\end{tabular}

Table 3. EDS analysis after quenching (K2).

\begin{tabular}{|c|c|c|c|}
\hline \multicolumn{2}{|c|}{ Result Type } & Weight \% & Weight \% \\
\hline \multicolumn{2}{|c|}{ Spectrum Label } & Spectrum 5 & Spectrum 6 \\
\hline \multicolumn{2}{|c|}{$\mathrm{Al}$} & 12.38 & 12.88 \\
\hline \multicolumn{2}{|c|}{$\mathrm{Ni}$} & 5.38 & 4.38 \\
\hline \multicolumn{2}{|c|}{$\mathrm{Cu}$} & 82.24 & 82.74 \\
\hline \multicolumn{2}{|c|}{ Total } & 100 & 100 \\
\hline Statistics & Al & $\mathrm{Ni}$ & $\mathrm{Cu}$ \\
\hline $\operatorname{Max}$ & 12.88 & 5.38 & 82.74 \\
\hline Min & 12.38 & 4.38 & 82.24 \\
\hline Average & 12.63 & 4.88 & 82.49 \\
\hline Standard deviation & 0.35 & 0.71 & 0.35 \\
\hline
\end{tabular}

According to Figures 4-6, where microstructures with different magnifications are presented, it can be concluded that both samples exhibited very good cavitation resistance. However, some differences between the samples were observed in OM and SEM images, indicating that the samples in the as-cast state exhibited better resistance to cavitation. 
An additional test for the surface damage determination was conducted using an atomic force microscope (AFM). Typical two-dimensional (2D) images of the sample in the as-cast state and after cavitation testing are presented in Figure 8.

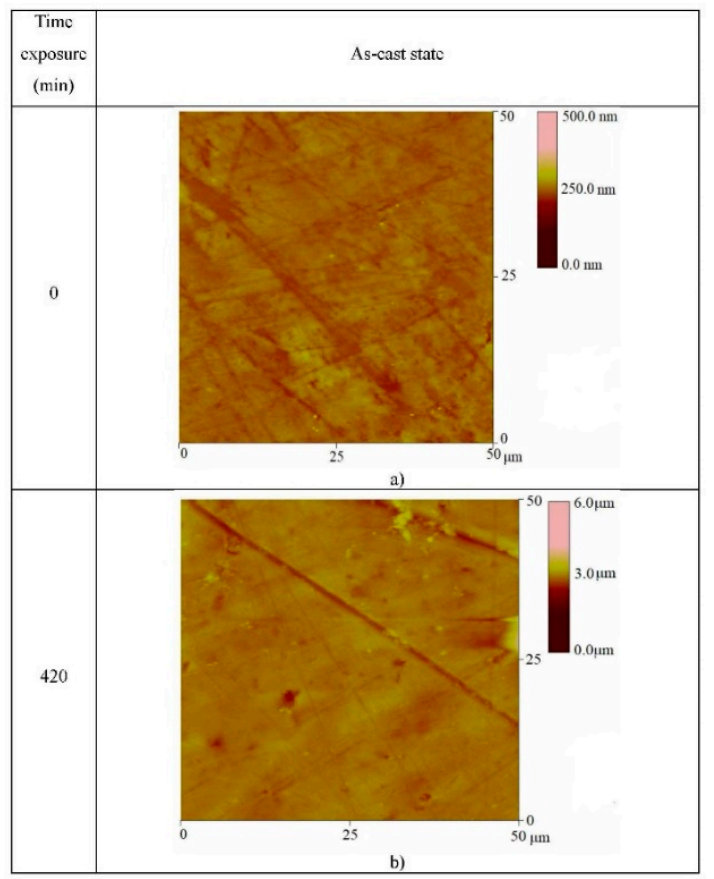

Figure 8. 2D AFM images of the sample in the as-cast state (a) before $\left(50 \times 150 \times 0.5 \mu \mathrm{m}^{3}\right)$ and (b) after $\left(50 \times 50 \times 6 \mu^{3}\right)$ cavitation testing for $420 \mathrm{~min}$.

The AFM images of the quenched sample before and after cavitation testing for 420 min are shown in Figure 9. Before cavitation testing, the sample after quenching exhibited roughness of $13.11 \mathrm{~nm}$, but after $420 \mathrm{~min}$ exposure to cavitation testing, roughness increased to $66.84 \mathrm{~nm}$.

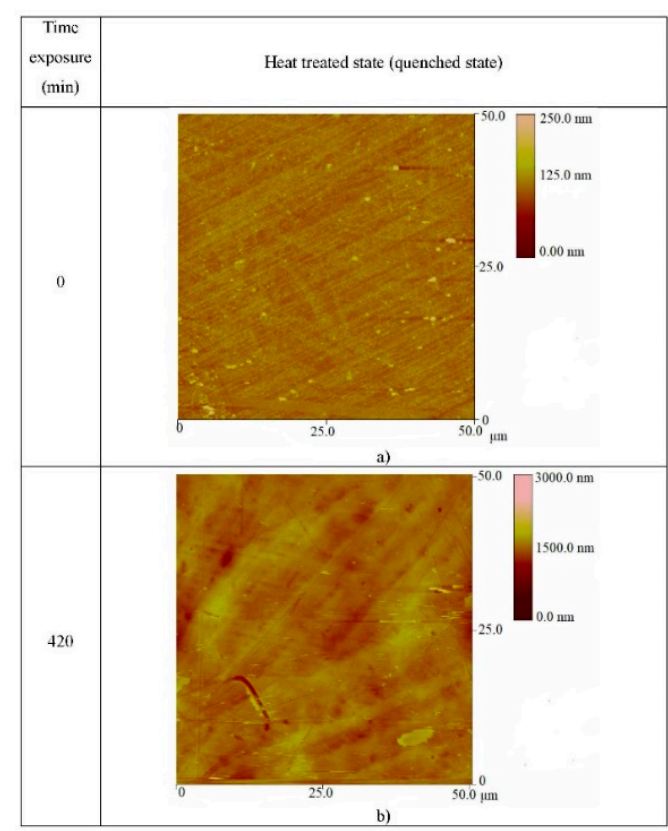

Figure 9. 2D AFM images of the sample after quenching: (a) before $\left(50 \times 50 \times 0.25 \mu \mathrm{m}^{3}\right)$ and (b) after $\left(50 \times 50 \times 3 \mu^{3}\right)$ cavitation testing for $420 \mathrm{~min}$. 
The results for surface roughness are listed in Table 4.

Table 4. Values of surface roughness of the samples in the different state and at different times of exposure to cavitation testing.

\begin{tabular}{ccc}
\hline State of Specimens & $\begin{array}{c}\text { Surface Roughness (nm) at } \\
\text { Time of Exposure of } \mathbf{0 ~ m i n}\end{array}$ & $\begin{array}{c}\text { Surface Roughness (nm) at } \\
\text { Time of Exposure of 420 min }\end{array}$ \\
\hline As-cast state & 9.33 & 84.185 \\
\hline Heat-treated (quenched) state & 13.11 & 66.846 \\
\hline
\end{tabular}

This method allows comparing these two samples, and the results for surface roughness pointed out the difference in their microstructure. Although both samples exhibited negligible mass loss difference during cavitation testing, according to the mass loss (Table 3), better cavitation resistance was observed for the sample in the as-cast state (L). Further analysis of morphological parameters given in Table 1 showed that all parameters that describe formed pits have grater values for the heat-treated state using quenching (K2), such as diameter, radius, and perimeter average area. Roughness measurements presented at Table 4 accompanied by the results of AFM (Figure 8) and previous results (mass loss, morphological parameters) before heat treatment showed better cavitation resistance for the sample in the as-cast state (L). For samples after $420 \mathrm{~min}$ of cavitation testing, roughness was lower for the heat-treated state. The influence of heat treatment on cavitation behavior of the samples can be related to different grain size, as it was about $150 \mu \mathrm{m}$ in the as-cast sample (Figures 1a and 2a), while after quenching, the average grain size was several times higher, up to about $1 \mathrm{~mm}$ (Figures $1 \mathrm{~b}$ and $2 \mathrm{~b}$ ). It is well known that grain size has a great influence on mechanical properties, as well as hardness, which can also be related to the cavitation resistance. The hardness values that were higher for the as-cast state confirmed this explanation for the behavior of the samples.

Before cavitation testing, the sample after quenching exhibited a similar value of surface roughness to the sample after casting.

However, after 420 min exposure to cavitation testing, better behavior was observed for the quenched sample (surface roughness of $66.846 \mathrm{~nm}$ ) compared with the sample after casting (surface roughness of $84.185 \mathrm{~nm}$ ).

The results of AFM monitoring presented in Table 4 and Figures 8 and 9 confirmed the excellent behavior of the samples during cavitation erosion testing. Differences in roughness were observed in samples before testing, as a higher value of roughness was observed for the heat-treated (quenched) state. After cavitation testing, roughness changed in a way such that the heat-treated sample showed lower roughness values, indicating better cavitation resistance.

The results of morphological analysis and surface roughness, which suggested better cavitation resistance for the as-cast state (L), can be correlated to the smaller grain size and better hardness of the sample.

The difference in the obtained microstructures before and after heat treatment can be explained by possible changes in martensite morphology. It is well known that functional properties of shape memory alloys depend on diffusionless martensite transformation between high temperature $\beta$-phase and low temperature martensite phase [35]. The previous work confirmed that, after heat treatment in CuAlNi shape memory alloy, along with $\beta_{1}{ }^{\prime}$ martensite, $\gamma_{1}{ }^{\prime}$ martensite also appears in the microstructure. CuAlNi shape memory alloys undergo a single transformation $\left(\beta \rightarrow \beta_{1}{ }^{\prime}\right.$ or $\left.\beta \rightarrow \gamma_{1}{ }^{\prime}\right)$ or a mixed transformation $\left(\beta \rightarrow \beta_{1}{ }^{\prime}+\right.$ $\left.\gamma_{1}{ }^{\prime}\right)$, which depends on alloys' chemical composition [36]. It can be concluded that the morphology of different types of martensite affects alloys' cavitation erosion resistance. Self-accommodating zig-zag $\beta_{1}{ }^{\prime}$ martensite provides benefits to alloys in terms of lower cavitation resistance, while the presence of $\gamma_{1}{ }^{\prime}$ martensite provides benefits to alloys in terms of better cavitation resistance. 
The obtained results for cavitation erosion can be related to other investigated materials. Compared with ceramic materials [27,29,30,38], it is usual that cavitation exposure time does not exceed $240 \mathrm{~min}$. However, for this time of exposure, the damage level was significantly higher, with more and larger pits created. A similar situation can be observed when metallic materials [39] or coatings were investigated [18,40]. For samples based on carbon steel [39], the exposure time was also $240 \mathrm{~min}$, as for coatings based on nickel and Cr3Si Film [18,40], where the exposure time was 240 and $180 \mathrm{~min}$. For these lower exposure intervals, samples had a higher level of degradation, as well as with the greater number and area of formed pits compared with the results obtained for the investigated samples (for as-cast state (L) and heat-treated (K2)). This comparison suggests that of the SMA materials, the polycrystalline $\mathrm{Cu}-12.8 \mathrm{Al}-4.1 \mathrm{Ni}$ (wt.\%) shape memory alloy exhibited excellent cavitation resistance.

\section{Conclusions}

Examination of the microstructure of $\mathrm{Cu}-12.8 \mathrm{Al}-4.1 \mathrm{Ni}$ (wt. \%) shape memory alloy reveals martensite microstructure after casting and heat treatment (quenching in water). The grain size of samples is higher after solution annealing and quenching in water than in the as-cast state. Martensite appears primarily as needle-like martensite. This microstructure consists of self-accommodating needle-like shape $\beta^{\prime} 1$ martensite in ascast state and after heat treatment. Measurements of microhardness showed that, after quenching in water, hardness was higher (480 HV10) than that in the as-cast state (344 HV10). Samples in as-cast and quenched state were investigated in order to measure the cavitation erosion behavior. After an exposure time of $420 \mathrm{~min}$ to cavitation erosion testing, very low values of mass loss were measured for both samples (as-cast and quenching state). Based on the obtained results, both samples showed excellent cavitation erosion resistance. Mass loss and morphological analysis of the formed pits pointed out differences between the samples and, based on the obtained results, better cavitation resistance was observed for the as-cast state (L).

Author Contributions: Conceptualization, T.V.-H. and M.G.; Synthesis, S.K. and I.I.; Methodology; S.K., I.I., S.S. (Sanja Stevanović). M.V. and S.M.; Formal Analysis, S.S. (Sanja Stevanović), S.S. (Srecko Stopic). and M.V.; Writing-Review \& Editing, M.V. and S.M.; Supervision, M.G.; Data Curation, S.M. and M.V. All authors have read and agreed to the published version of the manuscript.

Funding: This research was supported by the Ministry of Education, Science, and Technological Development of the Republic of Serbia (Contract Nos. 451-03-9/2021-14/200135 and 451-03-9/202114/200026) and by the Croatian Science Foundation (Project IP-2014-09-3405).

Conflicts of Interest: The authors declare that they have no conflict of interest.

\section{References}

1. Otsuka, K.; Wayman, C.M. Shape Memory Materials; Cambridge University Press: Cambridge, UK, 1998.

2. Lexcellent, C. Shape-Memory Alloys Handbook; John Wiley \& Sons: New York, NY, USA, 2013.

3. Jani, J.M.; Leary, M.; Subic, A.; Gibson, M.A. A review of shape memory alloy research, applications and opportunities. Mater. Des. 2014, 56, 1078-1113. [CrossRef]

4. Dasgupta, R. A look into Cu-based shape memory alloys: Present scenario and future prospects. J. Mater. Res. 2014, 29, 1681-1698. [CrossRef]

5. Arlic, U.; Zak, H.; Weidenfeller, B.; Riehemann, W. Impact of Alloy Composition and Thermal Stabilization on Martensitic Phase Transformation Structures in CuAlMn Shape Memory Alloys. Mater. Res. 2018, 21, 20170897. [CrossRef]

6. Agrawal, A.; Dube, R.K. Methods of fabricating Cu-Al-Ni shape memory alloys. J. Alloys Compd. 2018, 750, 235-247. [CrossRef]

7. Gojić, M.; Vrsalović, L.; Kožuh, S.; Kneissl, A.; Anzel, I.; Gudić, S.; Kosec, B.; Kliškić, M. Electrochemical and microstructural study of Cu-Al-Ni shape memory alloy. J. Alloys Compd. 2011, 509, 9782-9790. [CrossRef]

8. Lojen, G.; Gojić, M.; Anžel, I. Continuously cast Cu-Al-Ni shape memory alloy-Properties in as-cast condition. J. Alloys Compd. 2013, 580, 497-505. [CrossRef]

9. Pereira, E.C.; Matlakhova, L.; Matlakhov, A.N.; De Araújo, C.J.; Shigue, C.; Monteiro, S.N. Reversible martensite transformations in thermal cycled polycrystalline Cu-13.7\%Al-4.0\%Ni alloy. J. Alloys Compd. 2016, 688, 436-446. [CrossRef] 
10. Wang, Z.; Liu, X.-F.; Xie, J.-X. Effects of solidification parameters on microstructure and mechanical properties of continuous columnar-grained Cu-Al-Ni alloy. Prog. Nat. Sci. 2011, 21, 368-374. [CrossRef]

11. Hammit, F.G. Cavitation and Multiphase Flow Phenomena; McGraw-Hill: New York, NY, USA, 1980.

12. Franc, J.-P.; Michel, J.-M. Fundamentals of Cavitation; Springer Science and Business Media LLC: Berlin, Germany, 2005.

13. Okada, T.; Iwai, Y.; Hattory, S.; Tanimura, N. Relation between impact load and the damage produced by cavitation babble collapse. Wear 1995, 184, 231-239. [CrossRef]

14. Hattori, S.; Mori, H.; Okada, T. Quantitative Evaluation of Cavitation Erosion. J. Fluids Eng. 1998, 120, 179-185. [CrossRef]

15. Czyzniewski, K.A. Cavitation erosion resistance of Cr-N coating deposited on stainless steel. Wear 2006, 260, $1324-1332$.

16. Zhao, J.; Jiang, Z.; Zhu, J.; Zhang, J.; Li, Y. Investigation on Ultrasonic Cavitation Erosion Behaviors of Al and Al-5Ti Alloys in the Distilled Water. Metals 2020, 10, 1631. [CrossRef]

17. Szala, M.; Łatka, L.; Walczak, M.; Winnicki, M. Comparative study on the cavitation erosion and sliding wear of cold-sprayed $\mathrm{Al} / \mathrm{Al} 2 \mathrm{O} 3$ and $\mathrm{Cu} / \mathrm{Al} 2 \mathrm{O} 3$ coatings, and stainless steel, aluminium alloy, copper and brass. Metals 2020, 10, 856. [CrossRef]

18. Kazasidis, M.; Yin, S.; Cassidy, J.; Volkov-Husović, T.; Vlahović, M.; Martinović, S.; Kyriakopoulou, E.; Lupoi, R. Microstructure and cavitation erosion performance of nickel-Inconel 718 composite coatings produced with cold spray. Surf. Coatings Technol. 2020, 382, 125195. [CrossRef]

19. Singh, N.K.; Ang, A.S.; Mahajan, D.K.; Singh, H. Cavitation erosion resistant nickel-based cermet coatings for monel K-500. Tribol. Int. 2021, 159, 106954. [CrossRef]

20. Zakrzewska, D.E.; Krella, A.K. Cavitation Erosion Resistance Influence of Material Properties. Adv. Mater. Sci. 2019, 19, 18-34. [CrossRef]

21. Szala, M.; Chocyk, D.; Skic, A.; Kaminski, M. Effect of nitrogen ion implatation on the cavitation erosion resistance and cobalt-based solid solution phase transformations of HIPed Stellite 6. Metals 2021, 14, 2324.

22. Ding, X.; Ke, D.; Yuan, C.; Ding, Z.; Cheng, X. Microstructure and Cavitation Erosion Resistance of HVOF Deposited WC-Co Coatings with Different Sized WC. Coatings 2018, 8, 307. [CrossRef]

23. Cheng, F.; Shi, P.; Man, H. Cavitation erosion resistance of heat-treated NiTi. Mater. Sci. Eng. A 2003, 339, 312-317. [CrossRef]

24. Hattori, S.; Tainaka, A. Cavitation erosion of Ti-Ni base shape memory alloys. Wear 2007, 262, 191-197. [CrossRef]

25. Yang, L.; Tieu, A.; Dunne, D.; Huang, S.; Li, H.; Wexler, D.; Jiang, Z. Cavitation erosion resistance of NiTi thin films produced by Filtered Arc Deposition. Wear 2009, 267, 233-243. [CrossRef]

26. Wang, Z.; Zhu, J. Cavitation erosion of Fe-Mn-Si-Cr shape memory alloys. Wear 2004, 256, 66-72. [CrossRef]

27. Matovic, B.; Maksimovic, V.; Bucevac, D.; Pantic, J.; Lukovic, J.; Volkov-Husovic, T.; Gautam, D. Oxidation and erosion behaviour of SiC-HfC multilayered composite. Process. Appl. Ceram. 2014, 8, 31-38. [CrossRef]

28. Cheng, F.; Jiang, S. Cavitation erosion resistance of diamond-like carbon coating on stainless steel. Appl. Surf. Sci. 2014, 292, 16-26. [CrossRef]

29. Fatjo, G.G.-A.; Hadfield, M.; Tabeshfar, K. Pseudoplastic deformation pits on polished ceramics due to cavitation erosion. Ceram. Int. 2011, 37, 1919-1927. [CrossRef]

30. Martinović, S.; Vlahović, M.; Boljanac, T.; Dojčinović, M.; Volkov-Husović, T. Cavitation resistance of refractory concrete: Influence of sintering temperature. J. Eur. Ceram. Soc. 2013, 33, 7-14. [CrossRef]

31. Algellai, A.A.; Tomić, N.; Vuksanović, M.M.; Dojčinović, M.; Volkov-Husović, T.; Radojević, V.; Heinemann, R.J. Adhesion testing of composites based on Bis-GMA/TEGDMA monomers reinforced with alumina based fillers on brass substrate. Compos. Part $B$ Eng. 2018, 140, 164-173. [CrossRef]

32. Ashor, A.A.; Vuksanović, M.M.; Tomic, N.; Petrović, M.; Dojčinović, M.; Husović, T.V.; Radojević, V.; Heinemann, R.J. Optimization of modifier deposition on the alumina surface to enhance mechanical properties and cavitation resistance. Polym. Bull. 2019, 77, 3603-3620. [CrossRef]

33. Obradovic, V.; Vuksanovic, M.; Tomic, N.; Stojanovic, D.; Volkov-Husovic, T.; Uskokovic, P. Improvement in cavitation resistance of poly (vinyl butyral) composite films with silica nanoparticles: A technical note. Polym. Compos. 2021. [CrossRef]

34. ASTM. ASTM Standard G32-98 Standard, Test Method for Cavitation Erosion Using Vibratory Apparatus. In Annual Book of ASTM Standards; ASTM: West Conshohocken, PA, USA, 2000.

35. Recarte, V.; Pérez-Landazábal, J.; Rodríguez, P.; Bocanegra, E.; Nó, M.; Juan, J.S. Thermodynamics of thermally induced martensitic transformations in Cu-Al-Ni shape memory alloys. Acta Mater. 2004, 52, 3941-3948. [CrossRef]

36. Ivanić, I.; Kožuh, S.; Kurajica, S.; Kosec, B.; Anžel, I.; Gojić, M. XRD analysis of CuAlNi shape memory alloy before and after heat treatment. In Proceedings of the Mechanical Technologies and Structural Materials, Split, Croatia, 22-23 September 2016; Croatian Science Foundation: Opatija, Croatia, 2016; pp. 55-60.

37. Peña, J.; Gil, F.; Guilemany, J. Effect of microstructure on dry sliding wear behaviour in CuZnAl shape memory alloys. Acta Mater. 2002, 50, 3117-3126. [CrossRef]

38. Pošarac-Marković, M.; Veljovic, D.; Devečerski, A.; Matović, B.; Volkov-Husovic, T. Nondestructive evaluation of surface degradation of silicon carbide-cordierite ceramics subjected to the erosive wear. Mater. Des. 2013, 52, 295-299. [CrossRef]

39. Dojčinović, M.; Volkov-Husović, T. Cavitation damage of the medium carbon steel: Implementation of image analysis. Mater. Lett. 2008, 62, 953-956. [CrossRef]

40. Jiang, S.; Ding, H.; Xu, J. Cavitation Erosion Resistance of Sputter-Deposited Cr3Si Film on Stainless Steel. J. Tribol. 2016, 139, 014501. [CrossRef] 